\title{
KOMPARASI RISK DAN RETURN SAHAM DAN SAHAM SYARIAH
}

\author{
Setiyo Rini ${ }^{1}$, Abil Finda Farrukhy ${ }^{2}$ \\ Kharis Fadlullah Hana ${ }^{3}$ \\ IAIN Kudus ${ }^{1}$, IAIN Kudus ${ }^{2}$ IAIN Kudus ${ }^{3}$ \\ Setyarini464@gmail.com ${ }^{1}$, Abilfinda@gmail.com ${ }^{2}$ \\ kharis@iainkudus.ac.id ${ }^{3}$
}

\begin{abstract}
This research aims to identify the difference in the mean return and risk of regular and sharia stock listed on the Indonesia Stock Exchange as a provider of secondary data listed in the consumer goods industry in the 2019 period. The data analysis techniques in this research are using descriptive and inferential statistics analysis. The results of descriptive analysis within 1 year showed that the average return of regular stock is -0.0018342 or $-0.18 \%$ while the average return of Sharia stock 0,0009238 or $0.09 \%$. The risk level of regular stock during the period of 1 year is 0.0539309 or $5.39 \%$. while the risk level of sharia stock is 0.0142570 or $1.43 \%$. Based on the results of inferential analysis research using a different test (Independent Sample t-test), obtained result that there is no significant difference between return and risk of regular stock and Sharia stock.
\end{abstract}

Keywords: Return, Risk, Regular Stock, Sharia Stock

\section{Abstrak}

Penelitian ini bertujuan untuk mengidentifikasi perbedaan rata-rata return dan risk saham reguler dan saham syariah yang tercatat pada Bursa Efek Indonesia sebagai penyedia data sekunder yang tercantum di bidang industri barang konsumsi periode 2019. Teknik analisis data penelitian ini menggunakan analisis statistik deskriptif dan inferensial. Hasil analisis deskriptif pada kurun waktu 1 tahun menyatakan bahwa rata-rata return saham reguler senilai -0,0018342, sedangkan rata-rata return saham syariah senilai 0,0009238. Tingkat Risk saham reguler selama kurun waktu 1 tahun senilai 0,0539309, sedangkan tingkat risk saham syariah senilai 0,0142570. Berdasarkan hasil penelitian analisis inferensial dengan menggunakan uji beda (Independent Sample t-test) dihasilkan bahwa tidak ditemukan perbedaan signifikan antara return dan risk saham reguler dengan saham syariah.

Kata Kunci: Return, Risk, Saham Reguler, Saham Syariah 


\section{Pendahuluan}

Investasi di pasar modal saat ini telah menjadi bagian dari kehidupan masyarakat modern, seolah-olah kebutuhan mereka itu untuk mempertahankan atau menaikkan nilai aset mereka (Prasetyo, 2018). Investasi yang mudah bagi individu melibatkan jumlah yang dikonsumsi sekarang sehingga lebih banyak dikonsumsi di masa depan (Indra, 2018). Maka Investor akan berinvestasi, ini dikarenakan manfaat di masa depan yang disediakan dari penambahan rupiah yang diinvestasikan lebih besar daripada manfaat yang digunakan untuk keperluan saat ini. Pada umumnya investasi adalah penanaman modal dengan membeli satu atau lebih aset yang dimiliki pada suatu waktu dengan harapan mendapatkan keuntungan di masa depan. Investasi adalah satu hal yang dapat dilakukan untuk memanfaatkan atau menggunakan dana yang dibutuhkan oleh masyarakat dan diharapkan nanti dari investasi ini akan memberikan imbal balik (return). Dari sudut pandang Islam, investasi mempunyai pemahaman dan sasaran yang lebih luas karena melingkupi aspek dunia (material) dan akhirat (ukhrawi) (Karim et al., 2014). Ajaran Islam mengajarkan, kegiatan investasi bisa dimasukkan sebagai tindakan muamalah yang sangat disarankan, karena dengan menginvestasikan aset yang dimiliki menjadi produktif dan juga membawa manfaat bagi sesama. Seorang Muslim yang melakukan investasi sebaiknya dalam upaya untuk lebih dekat dengan Allah SWT. Banyak cara untuk menjalankan investasi, seperti halnya dengan membeli saham melalui pasar modal (Hadinata, 2018).

Pasar modal merupakan tempat yang memperdagangkan berbagai macam instrumen keuangan jangka panjang baik dalam bentuk modal sendiri maupun dalam bentuk hutang. Pasar Modal Syariah merupakan tempat yang dilaksanakan sesuai dengan prinsip syariat Islam (Herni Ruliatul Khasanah, 2016). Pasar modal konvensional dan pasar modal syariah terdapat perbedaan yang mendasar terlihat dari instrumen dan mekanisme transaksi yang dijalankan, perbedaan lainnya antara nilai indeks saham konvensional dan nilai indeks saham syariah terletak pada kriteria saham penerbit yang harus menjalankan prinsip-prinsip dasar Syariah (Rosyida, 2015). Perkembangan pasar modal syariah di Indonesia jika melihat dari perkembangan transaksi saham syariah memang menunjukkan peningkatan positif, tetapi kenaikannya belum bisa menunjukkan peningkatan return dan risk saham syariah lebih baik daripada saham reguler. Ini berhubungan dengan nilai investasi yang lebih kecil dibandingkan dengan berinvestasi di obligasi. Hal ini dilatarbelakangi karena saham adalah instrument investasi yang sangat terkenal baik dikalangan masyarakat investor saat ini (Zandi et al., 2014). Sedangkan saham syariah merupakan bentuk saham biasa yang mempunyai karakteristik tersendiri dalam bentuk pengamatan selektif terhadap aktivitas bisnis halal.

Beberapa hal yang perlu dipertimbangkan bagi seorang investor dalam berinvestasi, yaitu risk dan return saham (Prasetyo, 2018). Apabila kita membahas 
tentang risk saham dapat diartikan kita menganalisis harapan tidak tercapainya hasil (pengembalian). Penyimpangan yang semakin besar antara hasil nyata dan hasil yang diinginkan, itu berarti semakin besar risiko yang akan diterima. Risk berinvestasi di saham dikaitkan dengan kemungkinan atau probabilitas tingkat return (pengembalian) masa yang akan datang akan lebih kecil daripada yang akan diharapkan atau return-nya negatif (Prasetyo, 2018). Return adalah hasil yang didapat dari investasi (Dzanurrahmana Zein et al., 2019). Pendapatan investasi yang diperoleh dari saham adalah laba yang diperoleh dari penjualan dan pembelian saham, bila laba disebut capital gain dan ketika rugi disebut capital loss. Return dan risk merupakan trade off yang dipertimbangkan dalam investasi. Pengembalian yang semakin meningkat atau laba dari investasi yang dilakukan semakin tinggi pula risk atau risikonya. Risiko rendah, laba rendah; risiko tinggi, laba tinggi. Risk atau risiko dapat di minimalisir dengan melakukan investasi di sejumlah saham atau produk investasi yang lain atau biasa disebut diversifikasi (Albaity \& Ahmad, 2011). Akan tetapi, diversifikasi hanya dapat mengurangi unsystematic risk seperti resiko tingkat suku bunga, resiko likuiditas dan resiko bisnis. Adapun untuk systematic risk seperti risiko daya beli dan risiko pasar tidak dapat dihindari melalui diversifikasi (Herni Ruliatul Khasanah, 2016). Investor yang memutuskan akan berinvestasi biasanya mempertimbangkan return dan risk yang mungkin diperoleh. Perkembangan pasar modal syariah yang baik tidak selalu menggambarkan tingkat return dan risk saham syariah yang lebih baik daripada saham reguler. Investor harus mengetahui seberapa besar perbedaan tingkat return dan risk saham reguler dan saham syariah.

Beberapa penelitian terdahulu terkait return dan risk saham reguler maupun saham syariah di antaranya penelitian yang dilakukan oleh Sofyan Hadinata yang meneliti return dan risk saham dan saham syariah menunjukkan hasil bahwasannya tidak ditemukan perbedaan return mingguan antara saham reguler dengan saham Syariah (Hadinata, 2018). Tetapi untuk risiko secara statistik ditemukan perbedaan antara saham reguler dengan saham syariah. Selanjutnya untuk penelitian Ivan Yulian Rahma Putra dan Dinalestari P, didapatkan hasil bahwa tidak terdapat perbedaan yang signifikan antara return dan risk saham reguler dengan saham Syariah (Yulian et al., 2018). Hal ini menunjukkan bahwa hasil penelitiannya berbeda dengan penelitian sebelumnya. Berdasarkan berbagai penelitian terdahulu dengan adanya perbedaan dan kekurangan yang diuraikan di atas maka peneliti bermaksud untuk menguji lebih lanjut mengenai perbedaan antara return dan risk antara saham reguler dengan saham syariah. Dalam konteks ini peneliti akan membandingkan saham dan saham syariah di bidang industri barang konsumsi. 


\section{Kajian Literatur}

\section{Modern Portfolio Theory}

Modern Portfolio Theory merupakan pendekatan teoritis untuk menciptakan keputusan investasi yang berpusat pada pengembalian potensial dengan potensi risiko. Atau juga dapat dikatakan meminimalkan risiko untuk tingkat imbal hasil tertentu dengan hati-hati menentukan portofolio. Teori disini mengasumsikan bahwa jika seorang investor dihadapkan dalam 2 pilihan portofolio yang menawarkan tingkat return yang sama tetapi berbeda tingkat risikonya, sehingga investor dapat memilih portofolio yang memiliki tingkat risiko lebih rendah atau kenaikan risiko tersebut harus diimbangi dengan kenaikan tingkat imbal hasil. Teori yang dicetuskankan Herry Markowitz ini sangat banyak memberikan inspirasi untuk akademisi dan birokrat. Teori yang dikemukakan sangat sederhana yaitu "don't put all your eggs in one basket" (jangan menaruh telur di satu keranjang, tapi taruhlah dilebih dari satu keranjang). Sehingga menghasilkan konsep teori yang dikenal sebagai diversivikasi investasi yaitu menjalakan investasi yang sifatnya tidak berfokus di satu bidang saja tetapi lebih dari satu bidang serta dilakukan tidak juga dalam arah yang sama.

\section{Investasi}

Investasi adalah aktivitas di sektor keuangan yang dilakukan untuk memperoleh pengembalian terbesar di masa depan dari aset atau kekayaan yang ditanam. Pada umumnya investasi merupakan ditanamnya modal dengan cara membeli satu atau lebih aset yang dimiliki suatu saat di harapkan mendapat hasil keuntungan (Setiawan, 2017).

\section{Saham dan Saham syariah}

Saham merupakan sertifikat yang menyatakan bukti kepemilikan suatu perusahaan, dan investor dapat hak klaim atas pendapatan dan aset perusahaan (Tulung, Joy E, 2019). Sedangkan sahan syariah adalah sertifikat yang menyatakan bukti kepemilikan suatu perusahaan yang diterbitkan oleh penerbit dalam kegiatan usaha yang dijalankan ataupun cara mengelolaannya sesuai prinsip syariat islam (Binanga et al., 2017).

\section{Risk dan Return}

Risk merupakan peluang sesuatu tindakan yang memiliki efek berlawanan dengan tujuan yang hendak dicapai (Khaddafi \& Ferdiansyah, 2017). Atau bisa dikatakan penyimpangan pendapatan yang didapat pada investasi yang berlainan dengan pendapatan yang diterima. Sebagian risiko yang bisa saja muncul pada saat berinvestasi saham seperti: capital loss, tidak mendapatkan dividen, risiko suspend, risiko delisting saham, dan risiko bangkrut dan likuidasi. Metode pengukuran yang digunakan dalam penelitian ini adalah standar deviasi, 
selain dinyatakan dalam wujud varian. Standar deviasi bisa dihitung berdasarkan data historis. Standar deviasi untuk data historis bisa dihitung dengan cara:

$$
\begin{aligned}
& \sigma_{\mathrm{i}}=\sqrt{\sum_{\mathrm{i}=1}^{\mathrm{n}} \frac{\left[\left(\mathrm{R}_{\mathrm{it}}-\overline{\mathrm{R}}_{\mathrm{it}}\right)\right]^{2}}{\mathrm{n}-1}} \\
& \text { Keterangan: } \\
& \sigma \mathrm{i}=\text { standar deviasi return saham } \mathrm{i} \\
& \mathrm{n}=\text { periode saham } \\
& \overline{\mathrm{R}}_{\mathrm{it}}=\text { rata-rata return } \text { saham } \\
& \mathrm{R}_{\mathrm{it}}=\text { return saham } \mathrm{i}
\end{aligned}
$$

Return adalah ukuran tingkat pengembalian yang diperoleh. Return yang berasal dari investasi dalam saham diperoleh dari capital gain atau capital loss (Rosyida, 2015). Return saham adalah faktor utama yang membuat investor untuk berinvestasi dan juga imbalan dari keberanian investor untuk menanggung risiko investasi mereka. Return terbagi menjadi dua, yaitu return ekspektasi (expected return) dan return realisasi (realized return) (Basri \& Mayasari, 2019). Return realisasi adalah hasil yang telah terjadi dan bisa dihitung dengan data historis. Return realisasi dapat digunakan dalam menentukan return ekspektasi dan risiko di masa depan. Return realisasi diukur dengan menghitung dari selisih harga saham periode ini dengan periode harga saham sebelumnya dibagi dengan periode harga saham sebelumnya bisa disebut dengan capital gain atau capital loss.

$$
\text { Rit }=\frac{\mathrm{P}_{\mathrm{t}}-\mathrm{P}_{\mathrm{t}-1}}{\mathrm{P}_{\mathrm{t}-1}}
$$

Keterangan:

Rit $=$ Return saham I minggu ke-t

$\mathrm{P}_{\text {it }}=$ Harga saham I pada minggu ke- $\mathrm{t}$

$\mathrm{P}_{\mathrm{it}-1}=$ Harga saham I 1 minggu sebelum minggu ke-t

Sedangkan return ekspektasi sebagai imbal hasil yang ingin didapatkan bagi investor di masa depan. Perbeda antara return realisasi yang sifatnya sudah terbentuk, return ekspektasi bersifat belum terbentuk (Hadinata, 2018). Return ekspektasi bisa dihitung dengan menggunakan nilai-nilai return historis.

$$
\mathrm{E}\left(\mathrm{R}_{\mathrm{i}}\right)=\sum_{\mathrm{i}}^{\mathrm{n}} \frac{\mathrm{R}_{\mathrm{it}}}{\mathrm{n}} \mathrm{vb}
$$

Keterangan:

$\mathrm{E}(\mathrm{Ri})=$ Return ekspektasi (expected return) saham I

Rit = return saham I

$\mathrm{n}=$ Total dari hasil masa depan 


\section{Metode Penelitian}

Penelitian yang digunakan adalah pendekatan kuantitatif, yaitu penelitian yang menitikberatkan pada pengujian hipotesis melalui pengukuran variabel yang sedang diteliti dan akan menghasilkan penjelasan tentang suatu masalah dan menghasilkan generalisasi, serta melakukan analisis data dengan alat bantu statistik. Jenis data yang digunakan dalam penelitian yaitu data sekunder yang didapat dari website Bursa Efek Indonesia yaitu www.idx.co.id. Teknik analisis data yang digunakan pada penelitian ini yaitu menggunakan analisis statistik deskriptif dan inferensial. Metode sampling yang dipakai berupa metode purposive sampling dengan kriteria antara lain:

1. Saham reguler dan saham syariah yang terdaftar di bursa efek indonesia.

2. Saham reguler dan saham syariah di bidang industri barang konsumsi.

Dari kriteria-kriteria tersebut diperoleh sampel saham sebanyak 10 saham regular dan saham syariah sebanyak 10 saham. Selanjutnya disajikan daftar tabel saham reguler dan saham syariah.

Tabel 1: Daftar Sampel Saham Reguler

\begin{tabular}{|l|c|c|}
\hline No. & Kode & Nama saham \\
\hline 1. & ALTO & Tri Banyan Tirta Tbk. \\
\hline 2. & DLTA & Delta Djakarta Tbk. \\
\hline 3. & GGRM & Gudang Garam Tbk. \\
\hline 4. & HMPS & HuM Sampoerna Tbk. \\
\hline 5. & MLBI & Phapros Tbk. \\
\hline 6. & PEHA & Prasidha Aneka Niaga Tbk. \\
\hline 7. & PSDN & Bentoel Internasional Investama \\
\hline 8. & RMBA & Tunas Baru Lampung Tbk. \\
\hline 9. & TBLA & Wismilak Inti Makmur Tbk. \\
\hline 10. & WIIM & \\
\hline
\end{tabular}

Sumber: Data diolah

Tabel 2: Daftar Sampel Saham Syariah

\begin{tabular}{|l|c|c|}
\hline No. & Kode & Nama saham \\
\hline 1. & BTEK & Bumi Teknokultura Unggul Tbk \\
\hline 2. & BUDI & Budi Starch \& Sweetener Tbk. \\
\hline 3. & CLEO & Sariguna Primatirta Tbk. \\
\hline 4. & CINT & Chitose Internasional Tbk. \\
\hline 5. & DVLA & Darya-Varia Laboratoria Tbk. \\
\hline 6. & FOOD & Sentra Food Indonesia Tbk. \\
\hline 7. & KINO & Kino Indonesia Tbk. \\
\hline 8. & SIDO & Industri Jamu dan Farmasi Sido Muncul Tbk. \\
\hline 9. & ULTJ & Ultra Jaya Milk Industry \& Trading Company, Tbk. \\
\hline
\end{tabular}


\begin{tabular}{|l|l|l}
\hline 10. & WOOD & Integra Indocabinet Tbk. \\
\hline
\end{tabular}

Sumber: Data diolah

Jenis data yang dipakai pada penelitian ini adalah data sekunder yang diperoleh dari website Bursa Efek Indonesia. Analisis data yang dipakai dalam penelitian ini dengan menggunakan analisis statistik deskriptif dan inferensial.

1. Statistik deskriptif

Analisis statistik deskriptif pada penelitian ini adalah dihitungnya return dan risk saham regular dan saham Syariah. menghitung return memakai rumus dalam capital gain / loss adapun menghitung risk memakai rumus standar deviasi.

2. Statistik Inferensial

Analisis statistik Inferensial pada penelitian ini untuk menguji Independent Sample T-test tetapi terlebih dahulu menguji normalitas, dan uji homogenitas,

\section{Hasil dan Pembahasan}

\section{Statistik Deskriptif}

\section{a. Analisis return dan risk saham reguler}

Saham reguler yang berjumlah 10 sampel perusahaan yang didapatkan dari Bidang Industri Barang konsumsi. Return dihitung dengan memakai closing price (harga penutupan) saham mingguan yang diperoleh dari website Bursa Efek Indonesia. Return saham yang dihitung menghasilkan rata-rata return mingguan dan risk saham reguler dalam kurun waktu 1 tahun penelitian.

Tabel 3: Rata-rata return dan risk saham reguler di Bidang Industri Barang Konsumsi periode 2019

\begin{tabular}{|c|c|c|c|}
\hline No. & Nama Saham & Return & Risk \\
\hline 1. & ALTO & 0,000997 & 0,019371 \\
\hline 2. & DLTA & 0,003957 & 0,027463 \\
\hline 3. & GGRM & $-0,007384$ & 0,048451 \\
\hline 4. & HMSP & $-0,010808$ & 0,041331 \\
\hline 5. & MLBI & $-0,000458$ & 0,019729 \\
\hline 6. & PEHA & $-0,014801$ & 0,062293 \\
\hline 7. & PSDN & 0,001813 & 0,116310 \\
\hline 8. & RMBA & 0,001371 & 0,051109 \\
\hline 9. & TBLA & 0,002599 & 0,042637 \\
\hline 10 & WIIM & 0,004372 & 0,110615 \\
\hline Rata-rata & $-0,0018342$ & 0,0539309 \\
\hline Return tertinggi & 0,004372 & 0,116310 \\
\hline Return terendah & $-0,014801$ & 0,019371 \\
\hline
\end{tabular}

Sumber: Data diolah 
Diketahui dari tabel saham reguler yang bersumber dari Bidang Industri Barang Konsumsi selama tahun 2019 didapatkan return tertinggi yaitu perusahaan Wismilak Inti Makmur Tbk. senilai 0,004372 atau 0,44\%. Sedangkan perusahaan yang mempunyai Return terendah yaitu Phapros Tbk. senilai -0,014801 atau -1,48\%. Return yang didapat Phapros Tbk. memperoleh hasil yang negatif karena pada waktu penelitian, harga saham Phapros Tbk. mengarah mengalami penyusutan.

Rata-rata return saham reguler secara menyeluruh selama 1 tahun periode penelitian senilai $-0,0018342$ atau $-0,18 \%$. Hasil rata-rata return saham reguler tersebut didapatkan berdasarkan 6 return saham yang bernilai positif dan 4 return saham yang bernilai negatif.

Berdasarkan tabel di atas dapat dilihat bahwa perusahaan yang mempunyai tingkat risk tertinggi adalah perusahaan Wismilak Inti Makmur Tbk. yang memiliki Risk senilai 0,116310 atau 11,63\%. Adapun perusahaan yang mempunyai Risk terendah adalah Tri Banyan Tirta Tbk. senilai 0,019371 atau 1,94\%. Untuk saham reguler rentang antara tingkat risk tertinggi dengan tingkat risk terendah hampir lima kali lipat. Akan tetapi, secara generik saham reguler yang ada pada Bidang Industri Barang Konsumsi periode 2019 mempunyai rata-rata risk senilai 0,0539309 atau 5,39\%.

\section{b. Analisis return dan Risk Saham Syariah}

Saham Syariah berjumlah 10 sample Perusahaan yang didapatkan dari Bidang Industri Barang Konsumsi periode 2019. Return dihitung dengan memakai closing price (harga penutupan) saham mingguan yang diperoleh dari website Busa Efek Indonesia. Return saham yang dihitung menghasilkan rata-rata return mingguan dan risk saham syariah dalam kurun waktu 1 tahun penelitian.

Tabel 4: Rata-rata return dan risk saham di Bidang Industri Barang Konsumsi periode 2019

\begin{tabular}{|l|l|l|l|}
\hline No. & Nama Saham & Return & Risk \\
\hline 1. & BTEK & $-0,015600$ & 0,080398 \\
\hline 2. & BUDI & 0,000832 & 0,022179 \\
\hline 3. & CLEO & 0,012412 & 0,046979 \\
\hline 4. & CINT & 0,003309 & 0,046521 \\
\hline 5. & DVLA & 0,002984 & 0,031974 \\
\hline 6. & FOOD & $-0,018227$ & 0,013387 \\
\hline 7. & KINO & 0,004423 & 0,039603 \\
\hline 8. & SIDO & 0,009066 & 0,046139 \\
\hline 9. & ULTJ & 0,006196 & 0,033176 \\
\hline 10. & WOOD & 0,003843 & 0,052241 \\
\hline Rata-rata & 0,0009238 & 0,0142570 \\
\hline Return tertinggi & 0,012412 & 0,080398 \\
\hline Return terendah & $-0,018227$ & 0,013387 \\
\hline
\end{tabular}


Sumber: Data diolah

Berdasarkan tabel tersebut bisa dilihat antara 10 sampel perusahaan saham syariah pada Bidang Industri Barang Konsumsi periode 2019 yang mempunyai rata-rata return tertinggi selama 1 tahun yaitu Sariguna Primatirta Tbk. didapatkan nilai return senilai 0,012412 atau 1,24\%. Sedangkan rata-rata return paling rendah selama tahun 2019 diperoleh Sentra Food Indonesia Tbk. didapatkan nilai return senilai 0,018227 atau -1,82\%. Hasil return Sentra Food Indonesia Tbk. memperlihatkan return terendah lantaran selama 1 tahun penelitian tersebut harga saham Sentra Food Indonesia Tbk. tidak mengalami perubahan yang signifikan dan cenderung menurun. Mengenai rata-rata return saham syariah yang senilai 0,0009238 atau $0,09 \%$. Dikarenakan dari 10 sampel perusahaan saham syariah, didapatkan hasil return yang relatif sama, maka hasil rata-rata return saham syariah secara menyeluruh menunjukkan hasil tersebut.

Risk berdasarkan tabel tersebut bisa dilihat diantara sampel perusahaan saham syariah di Bidang Industri Barang Konsumsi periode 2019 mempunyai tingkat risk terendah selama 1 tahun yaitu Sentra Food Indonesia Tbk. yang mempunyai tingkat risk senilai 0,013387 atau $1,34 \%$. Sedangkan perusahaan yang mempunyai risk tinggi adalah Bumi Teknokultura Unggul Tbk yang mempunyai risk senilai 0,080398 atau $8,04 \%$. Biasanya saham Syariah yang terdapat pada Bidang Industri Barang Konsumsi periode 2019 mempunyai rata-rata risk sebesar 0,0142570 atau $1,43 \%$.

\section{Statis tik Inferensial}

Uji Independent Sample T-test atau uji beda dibutuhkan dalam memahami perbedaan rata-rata return dan risk saham reguler serta saham syariah. Tetapi sebelum melaksanakan uji Independent Sample T-test atau uji beda harus dilakukan uji normalitas juga uji homogenitas untuk syarat untuk melaksanakan uji Independent Sample T-test atau uji beda. Selanjutnya adalah hasil dari uji normalitas return saham. 
a. Uji Normalitas

Tabel 5: Hasil Uji Normalitas Return Saham

One-Sample Kolmogorov-Smirnov Test

\begin{tabular}{|ll|r|}
\hline & & $\begin{array}{c}\text { Unstandard } \\
\text { ized } \\
\text { Residual }\end{array}$ \\
\hline $\mathrm{N}$ & Mean & 10 \\
Normal & Std. Deviation &, 0000000 \\
Parametersa,b & Absolute &, 194 \\
Most Extreme & Positive &, 135 \\
Differences & Negative &,- 194 \\
&, 615 \\
Kolmogorov-Smirnov Z &, 844 \\
Asymp. Sig. (2-tailed) & &
\end{tabular}

a. Test distribution is normal.

b. calculated from data.

Sumber: Data diolah

Hasil yang didapatkan berdasarkan uji normalitas Return saham reguler dan Return saham syariah bahwa nilai Sig. $>$ nilai $\alpha$ pada nilai signifikasi 0,844 >0,05. Dari hasil signifikansi Return saham reguler dan saham syariah menyatakan bahwa nilai signifikansi lebih besar dari tingkat signifikansi $\alpha=5 \%(0,05)$ maka didapat kesimpulan maka data return saham reguler dan return saham syariah berdistribusi secara normal. Sesudah melaksanakan uji normalitas untuk return saham reguler dengan Return saham syariah berikutnya adalah melaksanakan uji normalitas untuk Risk saham reguler serta risk saham syariah. selanjutnya adalah hasil uji normalitas risk saham reguler serta risk saham syariah. 
Tabel 6: Hasil Uji Normalitas Risk Saham

One-Sample Kolmogorov-Smirnov Test

\begin{tabular}{|ll|r|}
\hline & & $\begin{array}{c}\text { Unstandard } \\
\text { ized } \\
\text { Residual }\end{array}$ \\
\hline $\mathrm{N}$ & Mean & 10 \\
Normal & Std. Deviation &, 0000000 \\
Parametersa,b & Absolute &, 1833415 \\
Most Extreme & Positive &, 180 \\
Differences & Negative &,- 103 \\
&, 570 \\
Kolmogorov-Smirnov Z &, 901 \\
\hline
\end{tabular}

a. Test distribution is Normal.

b. Calculated from data.

Sumber: Data diolah

Didapatkan hasil berdasarkan uji normalitas Risk saham reguler dan Risk saham syariah diketahui nilai Sig. $>$ nilai $\alpha$ pada nilai signifikansi $0,901>0,05$. Dengan signifikansi hasil risk saham reguler dan risk saham syariah menyatakan nilai signifikansi yang lebih besar dari tingkat signifikansi $\alpha=5 \%(0,05)$ didapat kesimpulan untuk data risk saham reguler dan risk saham syariah berdistribusi secara normal. Setelah uji normalitas pada risk saham reguler dengan risk saham syariah dilakukan, maka selanjutnya yaitu mengerjakan uji homogenitas. Kemudian yaitu hasil uji homogenitas data return saham reguler serta return saham syariah.

b. Uji Homogenitas

Tabel 7: Hasil Uji Homogenitas Return Saham

Test of Homogeneity of Variances

Rata-rata Return

\begin{tabular}{|r|r|r|r|}
\hline $\begin{array}{c}\text { Levene } \\
\text { Statistic }\end{array}$ & df1 & \multicolumn{1}{c|}{ df2 } & \multicolumn{1}{c|}{ Sig. } \\
\hline, 506 & 1 & 18 &, 486 \\
\hline
\end{tabular}

Sumber: Data diolah

Hasil yang didapatkan berdasarkan uji homogenitas yang diketahui membuktikan untuk nilai Sig. $>$ nilai $\alpha$ dengan nilai signifikansi 0,486 > 0,05, didapatkan kesimpulan untuk distribusi data adalah homogen. Sesudah melaksanakan uji homogenitas dari data return saham berikutnya adalah mengerjakan uji homogenitas untuk data risk saham. Selanjutnya adalah hasil uji homogenitas data risk saham. 
Tabel 8: Hasil Uji Homogenitas Risk Saham

Test of Homogeneity of Variances

Rata-rata Risk

\begin{tabular}{|r|r|r|r|}
\hline $\begin{array}{c}\text { Levene } \\
\text { Statistic }\end{array}$ & df1 & df2 & \multicolumn{1}{c|}{ Sig. } \\
\hline 2,536 & 1 & 18 &, 129 \\
\hline
\end{tabular}

Sumber: Data diolah

Hasil yang berasal dari uji homogenitas diketahui membuktikan untuk nilai Sig. $>$ nilai $\alpha$ dengan nilai signifikansi $0,129>0,05$, didapatkan kesimpulan untuk distribusi data adalah homogen. Bersumber pada hasil uji normalitas serta homogenitas atas data return dan risk memperlihatkan untuk data berdistribusi normal dan homogen maka melengkapi persyaratan akan dikerjakan pengujian hipotesis serta uji Independent Sample T-test.

\section{c. Uji Independent Sample T-test}

Pengujian hipotesis yang pertama yaitu pengujian data Return saham reguler dan Return saham syariah, prosedur uji statistiknya yaitu:

1. Menetapkan metode hipotesis pertama:

$\mathrm{H} 0=$ Tidak terdapat perbedaan antara return saham reguler dan Return saham syariah

$\mathrm{H} 1$ = Adanya perbedaan antara return saham reguler dan Return saham syariah

2. Menetapkan tingkat signifikan

Tingkat signifikansi yang dipakai adalah 5\% (0,05). Jika nila sig. (2-tailed) $>\alpha(0,05)$ maka H0 diterima dan H1 ditolak. Adapun jika nilai sig. (2-tailed) $<\alpha(0,05)$ maka $\mathrm{H} 1$ diterima dan $\mathrm{H} 0$ ditolak.

Sesudah menetapkan metode hipotesis serta tingkat signifikansi, tahap berikutnya adalah melaksanakan uji beda Independent Sample T-test atas data return saham reguler dan return saham syariah. Selanjutnya adalah hasil uji Independent Sample T-test. 
Tabel 9: Hasil Uji Independent Sample T-test Return Saham

\section{Independent Samples Test}

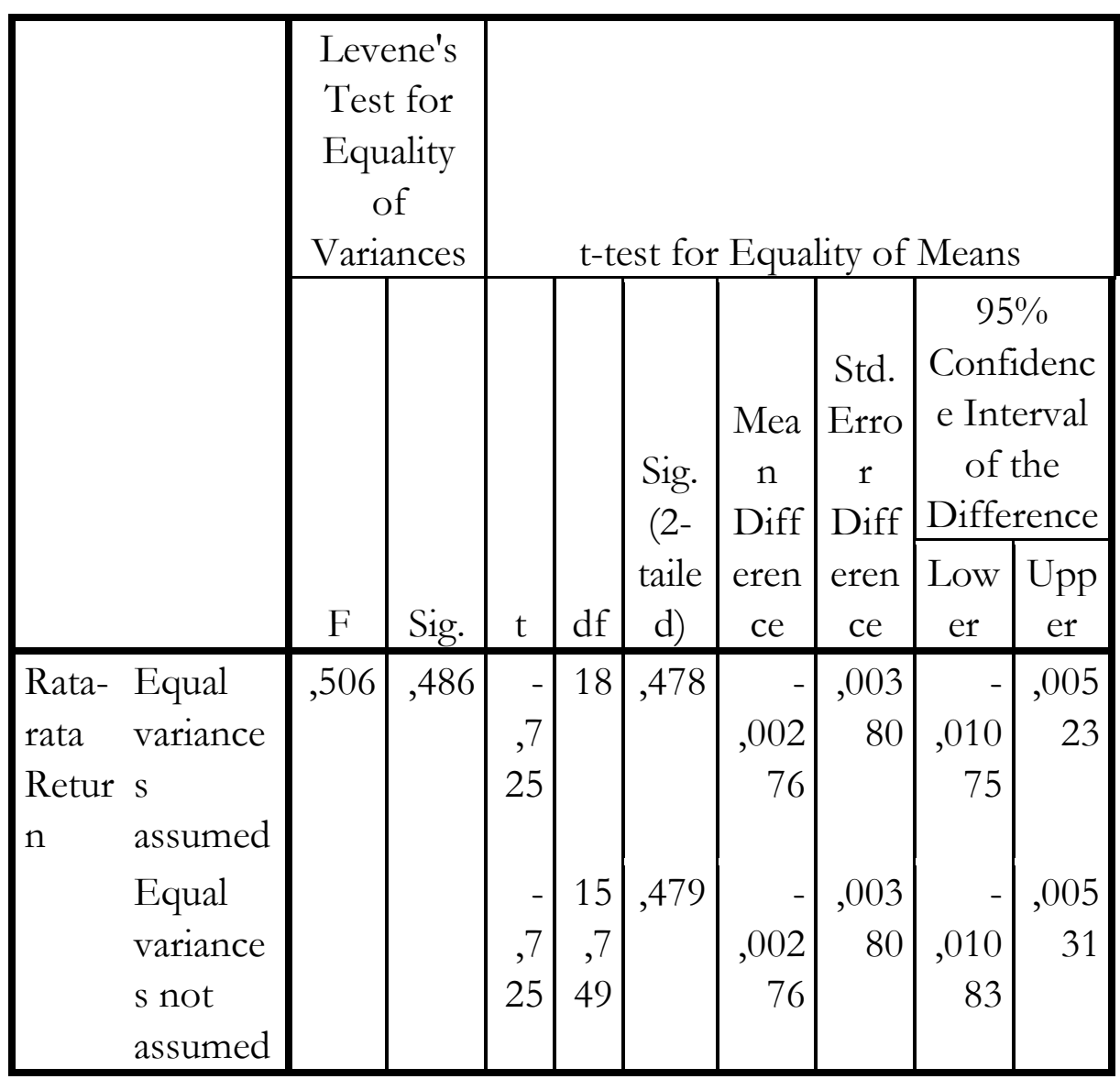

Sumber: Data diolah

Didapatkan hasil uji beda Independent Sample T-test tersebut menyatakan bahwa nilai $\mathrm{F}$ hitung levene adalah 0,506 untuk nilai sig. 0,486 > 0,05 hingga diperlukan asumsi Equal Variances Assumsed. Bersumber pada asumsi Equal V ariances Assumsed nilai Sig. (2-tailed) $>$ nilai $\alpha$ dengan nilai signifikansi 0,478>0,05. Dengan hasil signifikansi data Return saham menyatakan nilai signifikansi lebih besar dari tingkat signifikansi $\alpha=5 \%$ $(0,05)$ didapatkan kesimpulan hipotesis bahwa H0 diterima dan H1 ditolak yang dapat diartikan bahwa tidak adanya perbedaan yang signifikan antara return saham reguler dan return saham syariah.

Selanjutnya pengujian hipotesis kedua adalah pengujian data risk saham reguler serta risk saham syariah, prosedur uji statistiknya adalah:

1. Menetapkan metodekedua:

$\mathrm{H} 0=$ Tidak ditemukan perbedaan antara risk saham reguler dan risk saham syariah

H1 = Ditemukan perbedaan antara risk saham reguler dan risk saham syariah 
2. Menetapkan tingkat signifikan

Tingkat signifikan menggunakan 5\% $(0,05)$. Jika nilai sig. (2-tailed) $>$ $\alpha(0,05)$ maka $\mathrm{H} 0$ diterima dan $\mathrm{H} 1$ ditolak. Apabila nilai sig. (2-tailed) $<\alpha(0,05)$ maka H1 diterima dan H0 ditolak. Sesudah menetapkan metode hipotesis serta tingkat signifikan maka tahap berikutnya adalah melaksanakan uji Independent Sample T-test untuk data risk saham reguler dan risk saham syariah. Selanjutnya adalah hasil uji Independent Sample T-test.

Tabel 10: Hasil Uji Independent Sample T-test Risk Saham

\section{Independent Samples Test}

\begin{tabular}{|c|c|c|c|c|c|c|c|c|c|}
\hline & \multicolumn{2}{|c|}{$\begin{array}{c}\text { Levene's } \\
\text { Test for } \\
\text { Equality of } \\
\text { Variances }\end{array}$} & \multicolumn{7}{|c|}{ t-test for Equality of Means } \\
\hline & \multirow[b]{2}{*}{$\mathrm{F}$} & \multirow[b]{2}{*}{ Sig. } & \multirow[b]{2}{*}{$\mathrm{T}$} & \multirow[b]{2}{*}{$\mathrm{df}$} & \multirow{2}{*}{$\begin{array}{l}\text { Sig. } \\
(2- \\
\text { taile } \\
\text { d })\end{array}$} & \multirow{2}{*}{$\begin{array}{l}\text { Mea } \\
\mathrm{n} \\
\text { Diff } \\
\text { eren } \\
\text { ce }\end{array}$} & \multirow{2}{*}{$\begin{array}{c}\text { Std. } \\
\text { Erro } \\
r \\
\text { Diff } \\
\text { eren } \\
\text { ce }\end{array}$} & \multicolumn{2}{|c|}{$\begin{array}{c}95 \% \\
\text { Confidenc } \\
\text { e Interval } \\
\text { of the } \\
\text { Differenc } \\
\mathrm{e} \\
\end{array}$} \\
\hline & & & & & & & & $\begin{array}{c}\text { Low } \\
\text { er }\end{array}$ & $\begin{array}{l}\text { Up } \\
\text { per }\end{array}$ \\
\hline Rata- Equal & 2,53 &, 129 & 1,0 & 18 &, 316 & 012 & 012 & & 03 \\
\hline rata variances & 6 & & 31 & & & 67 & 29 & ,013 & 849 \\
\hline Risk assumed & & & & & & & & 15 & \\
\hline Equal & & & 1,0 & 13, &, 320 & ,012 & 012 & & ,03 \\
\hline variances & & & 31 & 77 & & 67 & 29 & ,013 & 907 \\
\hline not & & & & 3 & & & & 73 & \\
\hline assumed & & & & & & & & & \\
\hline
\end{tabular}

Sumber: Data diolah

Didapatkan hasil berdasarkan uji Independent Sample T-test tersebut untuk nilai $\mathrm{F}$ hitung dari levene adalah 2,536 dengan nilai sig. 0,129>0,05 maka asumsi yang digunakan yaitu Equal V ariances Assumsed. Dari asumsi Equal Variances Assumsed nilai Sig. (2-tailed) $>$ nilai $\alpha$ untuk nilai signifikansi 0,316>0,05. Karena hasil signifikansi data return saham menyatakan nilai signifikansi lebih besar dari tingkat signifikansi $\alpha=5 \%$ $(0,05)$ dapat disimpulkan hipotesis yang bisa didapat adalah $\mathrm{H0}$ diterima dan H1 ditolak yang dapat diartikan tidak terdapat perbedaan yang signifikan antara risk saham reguler dan risk saham syariah. 


\section{Pembahasan}

\section{Return Saham}

Diketahui hasil berdasarkan analisis deskriptif (amati tabel 3 dan tabel 4) yang menyatakan nilai return saham reguler senilai $-0,0018342$ atau $-0,18 \%$ tidak jauh beda dengan nilai return saham syariah senilai 0,0009238 atau $0,09 \%$. Apabila melihat pada analisis deskriptif selama 1 tahun rata-rata nilai return saham syariah memperlihatkan tingkat return yang cukup lebih tinggi dari saham reguler. Selanjutnya hasil uji normalitas (lihat tabel 5) Return saham reguler dan Return saham syariah diketahui nilai Sig. $>$ nilai $\alpha$ untuk nilai signifikansi 0,844 $>0,05$. Karena hasil signifikansi return saham reguler dan saham syariah menyatakan nilai signifikansinya lebih besar dari tingkat signifikansi $\alpha=5 \%$ $(0,05)$ lalu bisa disimpulkan bahwa data return saham reguler dengan return saham syariah terdistribusi secara normal. Berdasarkan hasil uji homogenitas (amati tabel 7) diketahui mendapatkan nilai Sig. $>$ nilai $\alpha$ dengan nilai signifikansi 0,486 $>0,05$, maka bisa diputuskan bahwa distribusi data adalah homogen. Diketahui hasil berdasarkan hipotesis dari uji Independent Sample T-test (amati tabel 9) untuk return saham reguler dan saham syariah menyatakan $\mathrm{H} 0$ diterima yang bisa diartikan bahwa tidak terdapat perbedaan rata-rata Return antara saham reguler pada bidang industri barang konsumsi periode 2019 dengan saham syariah pada bidang industri barang konsumsi periode 2019.

\section{Risk Saham}

Berdasarkan hasil dari analisis deskriptif (amati tabel 3 dan tabel 4) diketahui nilai risk saham reguler senilai 0,0539309 atau 5,39\% tidak berbeda jauh pada saham syariah dengan tingkat risk senilai 0,0142570 atau $1,43 \%$. Ratarata risk selama 1 tahun penelitian tersebut menunjukkan tingkat risk saham reguler lumayan cukup tinggi dari saham syariah. Berdasarkan hasil uji normalitas (amati tabel 6) Risk saham reguler dengan syariah diketahui nilai Sig. $>$ nilai $\alpha$ untuk nilai signifikansi $0,901>0,05$. Karena hasil signifikansi risk saham reguler dengan syariah memperlihatkan nilai signifikansinya cukup besar dari tingkat signifikansi $\alpha=5 \%(0,05)$ bisa disimpulkan bahwa data risk saham reguler serta risk saham syariah terdistribusi normal. Diketahui hasil berdasarkan uji homogenitas (amati tabel 8) yang menyatakan bahwa nilai Sig. > nilai $\alpha$ untuk nilai signifikansi $0,129>0,05$, bisa disimpulkan bahwa distribusi data adalah homogen. Berdasarkan hasil uji hipotesis memakai uji Independent Sample T-test (amati tabel 10) antara Risk saham reguler serta saham syariah memperlihatkan bahwa $\mathrm{H} 0$ diterima yang bisa diartikan tidak terdapat perbedaan yang signifikan antara risk saham reguler dari pada bidang industri barang konsumsi periode 2019 dengan saham syariah pada bidang industri barang konsumsi periode 2019.

\section{Perbandingan Return dan Risk Saham}

Diketahui hasil berdasarkan hipotesis pertama dan kedua menghasilkan bahwa tidak terdapat perbedaan siginifikan baik return maupun risk saham 
reguler dan saham syariah. Ini searah dengan penelitian sebelumnya yang dilakukan oleh Sofyan Hadinata berjudul "Tingkat Pengembalian (Return), Risiko, dan Koefisien Variasi pada Saham Syariah dan Saham Nonsyariah" oleh Sofyan Hadinata yang menunjukkan hasil bahwa tidak terdapat perbedaan return mingguan antara saham dengan saham syariah (Hadinata, 2018). Hasil penelitian ini sesuai dengan penelitian yang dilaksanakan oleh (Yulian et al., 2018) yang berjudul "Analisis Perbandingan Return dan Risk Saham Konvensional dan Syariah (Studi pada Jakarta Islamic Index (JII) dan IDX 30 Periode 2014-2018)" yang menyatakan bahwa tidak terdapat perbedaan signifikan mengenai return dan risk pada saham reguler dan saham syariah. Perbandingan pada return dan risk antara saham reguler dan syariah yang tidak begitu signifikan menunjukkan bahwa perkembangan pasar modal syariah yang cepat tidak langsung mengakibatkan return dan risk saham syariah lebih bagus atau berbeda daripada saham reguler. Akan tetapi, tidak mungkin untuk masa yang akan datang return (keuntungan) perolehan dari saham syariah akan melampaui return saham reguler. Dikarenakan pasar modal syariah di Indonesia saat ini terus bertumbuh. Perbandingan return dengan risk saham reguler dan syariah yang tidak jauh beda mengindikasikan saham syariah bukan tidak cocok untuk dipilih dalam berinvestasi. Akan tetapi, ini memperlihatkan bahwa investasi di saham syariah maupun reguler akan memperoleh hasil yang sama atau serupa.

\section{Kesimpulan}

Berdasarkan hasil dari penelitian ini dapat diketahui bahwa sannya tidak terdapat perbedaan signifikan antara return dan risk pada saham reguler dari bidang industri barang konsumsi periode 2019 dengan return dan risk saham syariah pada bidang industri barang konsumsi periode 2019. Rekomendasi bagi investor saham yang akan berinvestasi untuk memilih saham yang berlandaskan pada prinsip-prinsip syariah, karena return dan risk saham syariah lumayan tidak ada perbedaan dari saham reguler. Namun tidak menutup kemungkinan di masa depan keuntungan return atau pengembalian yang didapat dari saham syariah melebihi return saham reguler. Karena pesatnya pertumbuhan pasar modal syariah di Indonesia saat ini. 


\section{DAFTAR PUSTAKA}

Albaity, M., \& Ahmad, R. (2011). A comparative analysis of the firm specific determinants of Syariah compliant versus non-Syariah compliant firms in Bursa Malaysia. Asian Journal of Business and Accounting, 4(1), 59-84.

Basri, H., \& Mayasari, V. (2019). Perbandingan Kinerja Saham Syariah di Bursa Efek Indonesia dan Bursa Malaysia. JURNAL ILMLAH EKONOMI GLOBAL MASA KINI, 10(02).

Binanga, A., Dayyan, M., \& Mardhiah, A. (2017). Analisis Risk Dan Return Saham Syariah Tahun 2016. Jurnal Investasi Islam, 2(1), 89-112. http://journal.iainlangsa.ac.id/index.php/jii/article/view/274

Dzanurrahmana Zein, F., Aimmatul Umah, K., Asyaria, K., Herianingrum, S., Syifaul Qulub, A., \& Alif Rusmita, S. (2019). Optimization of ISSI Stock Portfolio using Single Index Models in 2013-2017. KnE Social Sciences, 3(13), 346. https://doi.org/10.18502/kss.v3i13.4215

Hadinata, S. (2018). Tingkat Pengembalian (Return), Risiko, dan Koefisien Variasi pada Saham Syariah dan Saham Nonsyariah. AKTSAR: Jurnal Akuntansi Syariah, 1(2), 171. https://doi.org/10.21043/aktsar.v1i2.5089

Herni Ruliatul Khasanah, S. W. (2016). Analisis perbandingan return dan risk saham syariah dengan saham konvensional (Studi pada Jakarta Islamic Index dan IDX30 periode 2014-2016). Jurnal Administrasi Bisnis, 58(2), 4655.

Indra, Y. A. (2018). Comparison of the Accuracy of Capital Asset Pricing Model and Arbitrage Pricing Theory Method in Predicting Stock Price (Study on Company Sector of Consumpted Goods and Mining Sectors Listed in Sharia Sharia Share Index (Issi). Journal of Economic, Business and Accounting (COSTING), 1(2). https://doi.org/10.1017/CBO9781107415324.004

Karim, B. A., Datip, E., \& Shukri, M. H. M. (2014). Islamic Stock Market Versus Conventional Stock Market. International Journal of Economics, Commerce and Management, II(11), 1-9.

Khaddafi, M., \& Ferdiansyah. (2017). Analisis perbandingan return dan risk ( Studi pada Saham Syariah dan Saham Konvensional LQ45 Periode ( 20122016 ). Jurnal Akuntansi Dan Keuangan, 5(1), 33-37.

Prasetyo, Y. (2018). Perbandingan Risiko Dan Return Investasi Pada Indeks Lq 45 Dengan Indeks Jakarta Islamic Index (JII). El-jizya : Jurnal Ekonomi Islam, 6(2), 287-310. https://doi.org/10.24090/ej.v6i2.2043

Rosyida, et al. (2015). Perbandingan tingkat pengembalian (Return), risiko dan koefisien variasi pada saham syariah dan saham non syariah di Bursa Efek Indonesia (BEI) periode 2011-2013. Jestt, 2(4), 288-304. https://doi.org/10.1017/CBO9781107415324.004

Setiawan, B. (2017). Perbandingan Kinerja Pasar Modal Syariah dan Konvensional : Suatu Kajian Empiris pada Pasar Modal Indonesia. Jurnal Ilmiah Ekonomi Global Masa Kini, 8(1), 35-40. 
Tulung, Joy E, Y. P. J. T. andIvonne S. S. (2019). Analisis Perbandingan Risiko Saham Jakarta Islamic Index Dan Indeks Lq45 Di Bursa Efek Indonesia. Jurnal EMBA: Jurnal Riset Ekonomi, Manajemen, Bisnis Dan Akuntansi, 7(3), 3239-3248.

Yulian, I., Putra, R., Dinalestari, P., \& Si, M. (2018). KONVENSIONAL DAN SYARIAH ( Studi pada Jakarta Islamic Index (JII) dan IDX 30 Periode 20142018) Tabel 1 : Tabel Pertumbuban Transaksi Saham Syariah 2011-2016 dan Risk saham syariah lebih baik dari saham konvensional. Seberapa besar perbedaan tingkat u. 1-11.

Zandi, G., Razak, D. A., \& Hussin, N. H. (2014). Stock market screening: An analogical study on conventional and shariah-compliant stock markets. $\begin{array}{llll}\text { Asian Social } & \text { Science, } & \text { 270-279. }\end{array}$ https://doi.org/10.5539/ass.v10n22p270 